\title{
PELATIHAN PENGEMBANGAN PERMAINAN UNTUK MENINGKATKAN PERKEMBANGAN SOSIAL EMOSIONAL ANAK
}

\author{
Oleh:
}

Muthmainnah, Budi Astuti, dan Arumi Savitri F

PAUD, BK, PAUD FIP Universitas Negeri Yogyakarta

Diwan_nafī yahoo.co.id; budi_astuti uny.ac.id; arumi.fatimaningrum yahoo.com

\begin{abstract}
Abstrak
Pelatihan ini bertujuan untuk meningkatkan pengetahuan guru tentang ragam permainan untuk meningkatkan perkembangan sosial emosional anak. Perkembangan sosial emosional yang dikembangkan meliputi percaya diri, tanggung jawab, komunikatif, kerjasama, kegigihan, dan kepedulian sosial. Kegiatan dilaksanakan melalui metode ceramah, tanya jawab, praktek/simulasi, dan pendampingan. Khalayak sasaran yang dituju dalam pelatihan ini adalah guru-guru TK di wilayah Imogiri yang berjumlah 30 guru.Evaluasi yang digunakan dalam pelatihan ini yaitu evaluasi penyelenggaraan dan evaluasi kemampuan guru dalam mempraktekkan permainan untuk anak. Untuk evaluasi penyelenggaraan digunakan angket yang diisi oleh peserta dan hasilnya $90 \%$ guru TK merasa materi yang disampaikan sesuai dan bermanfaat. Sedangkan evaluasi kemampuan guru dalam mempraktekkan permainan diperoleh hasil melebihi $80 \%$. Adapun permainan yang disimulasikan sebanyak 26 permainan.
\end{abstract}

Kata kunci: pelatihan, permainan, sosial emosional

Abstract
The training aims to improve teachers' knowledge about the various games to improve social emotional development of children. Social development emotional developed include self-confidence, responsibility, communicative, cooperation, persistence, and social concerns. The activities conducted through lectures, question and answer, practice / simulation, and mentoring. The intended target audience for this training are kindergarten teachers in the region Imogiri totaling 30 teachers. Evaluation used in this training is evaluation of the implementation and evaluation of a teacher's ability in practice game for kids. For the evaluation of the organization used a questionnaire completed by the participants and the results $90 \%$ of kindergarten teachers find material submitted appropriate and useful. While evaluating the ability of teachers to practice the game result exceeds $80 \%$. The game is simulated as much as 26 games.

Keywords: training, games, social, emotional

\section{PENDAHULUAN}

Usia dini merupakan usia emas (golden age), yang mana seluruh aspek perkembangan anak berlangsung sangat pesat. Pada usia emas ini, anak memiliki kepekaan dan kesiapan yang sangat baik untuk menerima rangsangan atau stimulasi dari luar. Stimulasi yang diberikan dapat berdampak positif bagi perkembangan anak, sehingga tumbuh kembang anak dapat diupayakan secara optimal dan mendukung perkembangan anak pada tahap selanjutnya. Adapun aspek perkembangan yang perlu dikembangkan pada anak meliputi aspek nilai agama moral, fisik motorik (motorik halus dan kasar), kognitif, bahasa, sosial emosional, dan seni. Keenam aspek tersebut harus dikembangkan secara proporsional dan seimbang.

Lembaga pendidikan anak usia dini seperti TK telah berupaya untuk 
membantu anak mengembangkan potensinya. Namun berdasarkan pengamatan, sebagian TK masih menekankan kegiatan pembelajaran pada kegiatan menyelesaikan LKA (Lembar Kegiatan Anak). LKA yang diselesaikan anak umumnya cenderung bersifat individual, sehingga kecerdasan interpersonal seperti kerjasama belum berkembang optimal. Aspek kemandirian juga kurang berkembang karena pendidik masih banyak membantu anak dalam menyelesaikan tugas. Selain itu, sebagian anak belum dibiasakan untuk tampil percaya diri melalui kegiatan pembelajaran yang membiasakan anak untuk berani berbicara dan unjuk kemampuan di depan kelas secara bergantian.

Kegiatan pembelajaran yang dirancang guru dengan menggunakan kegiatan bermain, baik di dalam kelas maupun di luar kelas juga masih terbatas atau jarang dilakukan. Kegiatan bermain di luar kelas biasanya dilakukan anak dengan bermain APE outdoor (perosotan, jungkat-jungkit, bola dunia, ayunan, dan lainnya) yang ada di halaman, sedangkan kegiatan bermain di dalam kelas dilakukan anak dengan bermain balok dan puzzle. Dunia anak sangat erat dengan kegiatan bermain. Melalui bermain, anak diajak untuk bereksplorasi, menemukan, dan belajar tentang lingkungannya. Anak juga dapat mengekspresikan potensi-potensi, bakat, kecerdasan, kreativitas, maupun dorongan untuk bergaul dalam suasana bermain (Mayke Tedjasaputra, 2001).

Berdasarkan wawancara dengan lima guru di wilayah kecamatan Imogiri diperoleh informasi bahwa guru memiliki keterbatasan pengetahuan tentang pengembangan permainan. Permainan yang seringkali dilakukan seperti main tangkap bola, lempar kantong biji, dan kucing tikus. Sedangkan permainan yang lain guru belum mampu merancang dan mengembangkannya.

Kegiatan pembelajaran lebh banyak dilakukan di meja dan kursi di dalam kelas, dengan menggunakan alat tulis seperti pensil, kertas, dan crayon. Kegiatan permainan masih sangat jarang dilakukan karena guru bingung dan belum memiliki gambaran. Kemampuan guru dalam mengembangkan berbagai kegiatan permainan yang variatif dan kreatif khususnya untuk pengembangan aspek sosial emosional masih perlu ditingkatkan agar pembelajaran terkesan tidak monoton pada pengerjaan LKA semata. Permainan dapat dikembangkan dalam permainan indoor maupun outdoor, serta dengan media maupun tanpa media.

Perumusan masalah dalam PPM ini adalah bagaimana meningkatkan pengetahuan guru TK dalam menerapkan metode permainan untuk mengembangkan kemampuan sosial emosional anak. Tujuan yang akan dicapai dalam PPM ini yaitu meningkatkan pengetahuan dan kreativitas guru TK dalam menerapkan metode permainan untuk mengembangkan kemampuan sosial emosional anak. Manfaat kegiatan dalam PPM ini yaitu untuk meningkatkan pengetahuan guruguru TK tentang pengembangan metode permainan mengembangkan kemampuan sosial emosional anak. Manfaat kedua untuk mendorong guru-guru TK agar lebih kreatif dalam mengembangkan metode permainan dalam pembelajaran.

\section{BERMAIN DAN PERMAINAN Pengertian Bermain}

Brooks dan Elliot (Tim Pustaka Familia, 2006) memaknai bermain sebagai kegiatan yang dilakukan untuk memperoleh kesenangan tanpa mempertimbangkan hasil akhir. Pendapat ini diperkuat oleh Siti Partini Suardiman (2003) yang mengungkapkan bahwa metode bermain merupakan metode pembelajaran yang mana anak-anak diajak melakukan kegiatan bersama dengan menggunakan alat atau tanpa alat, sendiri maupun dengan teman-temannya, yang mendatangkan kegembiraan, rasa senang, dan asyik pada anak.

Dunia anak sangat erat dengan kegiatan bermain. Melalui bermain, anak 
diajak untuk bereksplorasi, menemukan, dan belajar tentang lingkungannya. Anak juga dapat mengekspresikan potensipotensi, bakat, kecerdasan, kreativitas, maupun dorongan untuk bergaul dalam suasana bermain (Mayke Tedjasaputra, 2001). Soetarlinah Sukadji mengungkapkan bahwa melalui bermain, anak-anak pun menjadi tidak merasa terpaksa dalam melakukan kegiatan belajar, karena belajar melalui bermain menjadi kegiatan yang menyenangkan bagi anak (Agoes Dariyo: 2007). Johnson, Christie \& Yawkey (1999) menyatakan bahwa bermain memberikan empat manfaat yaitu mengembangkan kreatifitas, keterampilan sosial, keterampilan psikomotorik, kemampuan berbahasa, dan sebagai sarana terapi untuk mentasi masalah psikologis. Bermain dapat menurunkan atau mengurangi kecemasan dan kegelisahan anak-anak (Barnett dan Strom, dalam BEF Montolalu, 2008). Ungkapan perasaan negatif, permusuhan, penyerangan dapat disalurkan melalui tanah liat atau plastisin yang ditumbuktumbuk, bola yang ditendang atau dilempar. Selain itu, permainan juga dapat meningkatkan kepekaan emosi anak, dimana orang tua dan pendidik dapat mengenalkan bermacam-macam perasaan (perasaan saat menang dan kalah, mengenalkan perubahan perasaan (dari senang ke sedih dan sebaliknya), membuat pertimbangan, mengendalikan diri (contohnya menerima kekecewaan, mengungkapkan kepuasan), dan menumbuhkan kepercayaan diri. Yang termasuk permainan kompetitif contohnya estafet bendera, ambilkan sepatuku, menangkap burung, menjala ikan, jalan kepiting, dan sebagainya.

$$
\text { Apabila ditinjau dari }
$$

pelaksanaannya, kegiatan bermain terdiri dari bermain bebas dan bermain terpimpin. Bermain bebas merupakan kegiatan yang mana anak-anak boleh memilih kegiatan dan alat bermain yang disukai, serdangkan kegiatan bermain terpimpin merupakan kegiatan bermain yang telah dipersiapkan guru dan disesuaikan dengan tema. Aktifitas dalam kegiatan bermain terpimpin seperti permainan dalam lingkaran, permainan dengan alat, permainan tanpa alat, permainan dengan nyanyian, permainan dalam bentuk lomba, permainan dengan angka, dan permainan mengasah panca indera (BEF Montolalu: 2009). Dalam menata ruang dan tempat bermain, perlu diperhitungkan bukan hanya untuk seorang anak melainkan untuk kelompok anak. Tempat dan ruang bermain terdiri dari ruang di dalam kelas (indoor) maupun di luar kelas (outdoor) (Moeslichatoen: 2004).

Peran pengasuh, pendidik atau guru dalam kegiatan bermain sangatlah penting, yaitu sebagai perencana, fasilitator, pengamat, model, motivator, dan teman bermain anak. Apabila pengasuh dan atau pendidik dapat berperan secara optimal, diharapkan perkembangan anak dapat tercapai melalui kegiatan bermain yang kreatif, inovatif, menarik dan menyenangkan.

\section{Langkah-langkah Metode Bermain}

Terdapat beberapa langkah dalam kegiatan bermain, antara lain:

Persiapan

Pada tahap persiapan, hal yang perlu dilakukan yaitu:

a. Guru menentukan tujuan dan tema kegiatan bermain.

b. Guru menentukan jenis permainan yang akan dilakukan dan sebaiknya disesuaikan dengan tujuan pembelajaran. Dalam menentukan jenis permainan, guru juga harus mempertimbangkan karakteristik usia kelompok anak, sehingga anak-anak tidak merasa kesulitan dalam memainkannya.

c. Guru menyiapkan bahan dan peralatan yang diperlukan untuk permainan. Bahan dan peralatan yang digunakan sebaiknya bahan yang mudah diperoleh, mudah dibuat, dan aman. 
d. Guru menata ruangan untuk mempermudah pelaksanaan permainan.

Pelaksanaan

Pada tahap pelaksanaan, hal yang perlu dilakukan yaitu:

a. Guru mengkondisikan anak-anak untuk mempersiapkan diri sebelum kegiatan, misalnya dengan mengatur tempat duduk.

b. Guru juga perlu memastikan agar permainan dapat dilakukan dengan aman misalnya meminta anak melepas kaos kaki agar tidak terpeleset nantinya saat berlari di atas lantai, dan aturan teknis lainnya.

c. Guru menjelaskan aturan main dan memastikan anak-anak sudah memahami aturan main sebelum permainan dimulai. Hal ini dapat dilakukan dengan menanyakan kembali atau re-chek melalui pertanyaan tentang aturan permainan.

d. Anak-anak dibagi menjadi kelompok bila permainan yang dilakukan adalah permainan kelompok. Apabila permainan yang dilakukan adalah permainan individu, guru dapat menunjuk atau menawarkan pada anak untuk langsung bermain.

e. Guru mendampingi anak saat permainan serta memberikan motivasi.

f. Guru mengamati dan mencatat perkembangan anak selama bermain.

g. Guru memberikan apresiasi pada usaha anak.

h. Guru memberikan pemahaman tentang nilai-nilai yang ada dalam permainan dan mendorong anak agar menerapkan nilai-nilai tersebut dalam kehidupan.

Penutup

Pada tahap penutup, hal yang perlu dilakukan yaitu melakukan evaluasi agar pelaksanaan kegiatan bermain berikutnya dapat berjalan lebih baik.

\section{PERKEMBANGAN EMOSIONAL}

SOSIAL

Perkembangan sosial emosional mencakup dua macam perkembangan yaitu perkembangan sosial dan emosi yang saling berkaitan. Perkembangan sosial mengarah pada kemampuan anak untuk berinteraksi dan menyesuaikan diri dengan orang lain, sehingga dapat diterima secara sosial. Di sisi lain, perkembangan emosional mengarah pada kemampuan anak untuk mengenal emosi (diri, orang lain), mengekspresikan emosi, serta memberikan reaksi emosi secara positif. Dari pengertian tersebut dapat disimpulkan bahwa perkembangan sosial emosional yaitu perkembangan yang melatih anak agar mampu mengendalikan diri dan mengekspresikan emosi secara positif, sehingga dapat menyesuaikan diri dengan lingkungan dan diterima secara sosial.

Pengembangan kemampuan sosial anak dapat diarahkan sesuai lingkup perkembangan anak. Salah satunya mengacu pada tingkat pencapaian perkembangan anak yang ada dalam kurikulum PAUD yaitu: mau berbagi, menolong, dan membantu teman; menunjukkan antusiasme dalam melakukan permainan kompetitif secara positif; menaati aturan yang berlaku dalam suatu permainan; menjaga diri sendiri dari lingkungannya; dan menghargai orang lain. Pengembangan sosial diharapkan dapat mengarahkan anak dari sifat egosentris ke arah sosiosentris, memperluas pertemanan anak, menjalin persahabatan, belajar tentang tata krama, berperan serta dalam kelompok, dan membantu anak belajar menyesuaikan diri agar dapat diterima secara sosial. Sedangkan pengembangan emosi anak meliputi menunjukkan sikap mandiri, mengendalikan perasaan, menunjukkan rasa percaya diri, menunjukkan sikap toleran, mengekspresikan emosi sesuai dengan keadaan, menunjukkan rasa empati 
yaitu memahami perasaan dan masalah orang lain, berpikir dari sudut pandang orang lain, mampu menghargai perbedaan orang lain, memiliki sikap gigih (tidak mudah menyerah) dan bangga dengan hasil karya sendiri.

\section{Khalayak Sasaran}

Khalayak sasaran yang dituju dalam pelatihan ini adalah guru-guru TK di wilayah Imogiri yang berjumlah 30 guru.

\section{METODE KEGIATAN}

Kegiatan dilaksanakan dalam bentuk ceramah, tanya jawab, praktek/simulasi, dan pendampingan. Metode ceramah digunakan untuk memberikan pemahaman pada peserta tentang metode permainan, penerapan dan strategi pengembangannya. Metode tanya jawab dilakukan untuk memperkuat pemahaman peserta selama dan setelah ceramah. Selanjutnya digunakan praktek/simulasi untuk mempertajam pemahaman guru dan memberikan kejelasan dalam langkah-langkah penerapan permainan untuk anak. Paska pelatihan, tim pengabdi/PPM memberikan kesempatan pada para peserta untuk menerapkan dan mengembangkan permainan di TK masing-masing dan tim pengabdi melakukan monitoring dan membantu guru-guru TK daam mengembangkan permainan. Dalam pendampingan, tim pengabdi menanyakan ragam permainan mana saja yang telah diterapkan di TK, mendiskusikan solusi kendala teknis permainan, dan mendorong guru untuk mengembangkan permainan sesuai kreativitas, kondisi lahan TK, dan bahan/alat yang terseda untuk permainan.

\section{Evaluasi}

Evaluasi yang digunakan dalam program ini yaitu evaluasi program dan evaluasi kemampuan guru dalam merancang permainan untuk anak. Untuk evaluasi penyelenggaraan digunakan angket yang diisi oleh peserta (format evaluasi terlampir). Adapun hasil angket menunjukkkan $90 \%$ peserta pelatihan menyatakan respon positif (materi jelas, sesuai dan bermanfaat) dalam penyelenggaraan program. Selain itu, untuk evaluasi kemampuan guru dalam mempraktekkan permainan diperoleh hasil dari tiga TK dapat menerapkan 10-16 permainan yang telah disampaikan saat pelatihan. Secara keseluruhan terdapat 26 permainan yang dilatihkan, dan beberapa TK belum bisa menerapkan semua permainan karena harus mengaitkan permainan dengan tema pembelajaran.

\section{HASIL PELAKSANAAN KEGIATAN}

Pelatihan pengembangan metode pembelajaran untuk meningkatkan keterampilan sosial anak TK dilaksanakan dengan melibatkan guru-guru TK di wilayah Kecamatan Imogiri Bantul yang berjumlah 30 peserta. Kegiatan ini dilakukan dengan metode ceramah, tanya jawab, simulasi permainan/praktek, serta pendampingan. Kegiatan pelatihan dilaksanakan pada hari Sabtu, tanggal 23 Juli 2016. Kegiatan ini terbagi ke dalam 3 (tiga) sesi. Adapun deskripsi pelaksanaan kegiatan pelatihan sebagai berikut:

Sesi Pertama (Ceramah dan tanya jawab)

Pelaksanaan sesi pertama diisi dengan ceramah yang berjudul "Permainan sebagai Metode Pembelajaran AUD” yang disampaikan oleh Ibu Muthmainnah, M.Pd. Perlunya diberikan materi pelatihan ini agar para guru TK mampu memahami tentang pengertian permainan dan ragam permainan untuk meningkatkan keterampilan sosial emosional anak TK. Materi ini memberikan pemahaman bahwa permainan dapat dirancang dengan sederhana, baik di dalam ruangan maupun di luar ruangan, dengan media maupun tanpa media, dan dapat dikembangkan sesuai kreativitas guru. Pengabdi mendorong para guru TK untuk berani merancang permainan 
yang inovatif dan kreatif, serta percaya diri untuk mempraktekkannya di TK agar anak semakin antusias dalam mengikuti kegiatan, dan tentunya mendukung perkembangan, khususnya perkembangan sosial emosional anak. Pengabdi juga memberikan dorongan agar para guru TK dapat mengembangkan permainan atau mengkreasi permainan dengan menyesuaikan dengan ketersediaan media, kondisi lokasi, dan kreativitas guru. Setelah kegiatan ceramah kemudian dilanjutkan dengan kegiatan tanya jawab.

Sesi Kedua (Simulasi Permainan)

Pelaksanaan sesi kedua diisi dengan simulasi permainan yang dipandu oleh Ibu Muthmainnah, M.Pd, Ibu Dr. Budi Astuti, M.Pd dan Ibu Arumi Savitri F, S.Psi,M.A. Perlunya diberikan simulasi atau praktek permainan ini agar para guru TK memiliki kejelasan dalam langkahlangkah permainan. Para guru tampak antusias dalam melakukan permainan, sehingga suasana kelas menjadi hidup dan lebih menyenangkan. Adapun permainan yang disimulasikan adalah permainan bola perkenalan, jalan kepiting, lompati simpai, bola beranting, gobag bundar simpang tiga, guru berkata...., berbaris sesuai urutan angka, urutkan dengan garis, ayo.....mengurutkan, gambar berantai, pesan berantai, cerita berantai, pindahkan aku, aku berguna untuk...., tebak benda, tebak gerak, menggiring balon, mencari teman, mencari potongan yang sesuai, awal sebuah kata, bantu aku menemukan, memilih kemudian menggunting dan menempel, estafet bendera (merangkak, melompat, berlari), ambilkan sepatuku, kapal karam, dan pijat, palu, babat.

Dengan adaya simulasi permainan, diharapkan para peserta dapat mempraktekkan dan mengembangkan permainan di TK masing-masing. Sesi Ketiga (Pendampingan)

Kegiatan sesi ketiga dilakukan
pendampingan dimana pengabdi
melakukan monitoring terhadap
penerapan permainan AUD yang telah
dilatihkan di beberapa TK.

\section{PEMBAHASAN}

Bermain merupakan salah satu metode yang efektif bagi anak usia dini. Selain menyenangkan, metode ini membuat anak belajar sambil bermain. Saat melakukan pendampingan di beberapa TK, guru menyampaikan bahwa anak-anak lebih antusias jika diajak belajar melalui kegiatan bermain. Anak tampak semangat dan menikmati kegiatan. Hal ini sesuai dengan pendapat Soetarlinah Sukadji yang mengungkapkan bahwa melalui bermain, anak-anak pun menjadi tidak merasa terpaksa dalam melakukan kegiatan belajar, karena belajar melalui bermain menjadi kegiatan yang menyenangkan bagi anak (Agoes Dariyo: 2007).

Paska pelatihan guru-guru telah mempraktekkan beberapa permainan seperti permainan bola perkenalan, jalan kepiting, lompati simpai, bola beranting, gobag bundar simpang tiga, guru berkata...., berbaris sesuai urutan angka, urutkan dengan garis, ayo.....mengurutkan, gambar berantai, pesan berantai, cerita berantai, pindahkan aku, aku berguna untuk...., tebak benda, tebak gerak, menggiring balon, mencari teman, mencari potongan yang sesuai, awal sebuah kata, bantu aku menemukan, memilih kemudian menggunting dan menempel, estafet bendera (merangkak, melompat, berlari), ambilkan sepatuku, kapal karam, dan pijat, palu, babat. Seluruh permainan yang telah dipraktekkan terbukti dapat mengembangkan kemampuan sosial emosional seperti percaya diri, tanggung jawab, kerjasama, gigih, membiasakan komunikasi, membantu teman; menunjukkan antusiasme dalam melakukan permainan kompetitif secara positif, menaati aturan yang berlaku dalam suatu permainan, dan nilai-nilai sosial 
emsional lainnnya. Hal ini sesuai dengan pendapat Johnson, Christie \& Yawkey (1999) yang menyatakan bahwa bermain memberikan empat manfaat yaitu mengembangkan kreativitas, keterampilan sosial, keterampilan psikomotorik, kemampuan berbahasa, dan sebagai sarana terapi untuk mengatasi masalah psikologis.

Permainan-permainan yang

disimulasikan dan diterapkan dalam kegiatan ini termasuk aktivitas bermain terpimpin karena meliputi permainan dalam lingkaran, dengan alat dan tanpa alat, menggunakan angka, dan mengasah panaca indera. Hal ini sesuai dengan pendapat BEF Montolalu (2009) yang menjelaskan bahwa aktifitas dalam kegiatan bermain terpimpin yaitu permainan dalam lingkaran, permainan dengan alat, permainan tanpa alat, permainan dengan nyanyian, permainan dalam bentuk lomba, permainan dengan angka, dan permainan mengasah panca indera.

Beberapa permainan dilakukan di dalam ruangan maupun di luar ruangan, sehingga guru menata tempat bermain. Hal ini sesuai dengan pendapat Moeslichatoen (2004) bahwa tempat dan ruang bermain terdiri dari ruang di dalam kelas (indoor) maupun di luar kelas (outdoor). Dalam permainan, guru memiliki beberapa peran yaitu sebagai perencana, fasilitator, pengamat, model, motivator, dan teman bermain anak. Apabila pengasuh dan atau pendidik dapat berperan secara optimal, diharapkan perkembangan anak dapat tercapai melalui kegiatan bermain yang kreatif, inovatif, menarik dan menyenangkan.

\section{Faktor Pendukung dan Penghambat Kegiatan}

\begin{tabular}{lrr}
\multicolumn{2}{c}{ Kegiatan } & pelatihan \\
pengembangan & permainan & untuk \\
meningkatkan kemampuan & sosial \\
emosional anak terlaksana berkat & kerja \\
sama antar anggota Tim PPM & yang \\
dibantu mahasiswa, adanya kerja sama & sama \\
dengan IGTK di wilayah kecamatan
\end{tabular}

Imogiri Bantul, dan antusiasme para guru TK di kecamatan Imogiri Bantul. Tempat serta fasilitas kegiatan didukung oleh TK Masyithoh Dukuh Imogiri yang bekerja sama dengan Fakultas Ilmu Pendidikan UNY dalam hal ini diwakili oleh dosen PGPAUD FIP UNY selaku tim pelaksana kegiatan PPM. Pada pelaksanaan kegiatan pelatihan, ada beberapa hambatan yaitu kelas yang digunakan agak sempit dan beralaskan karpet, sehingga membatasi gerak saat simulasi permainan. Namun secara keseluruhan, kegiatan dapat berjalan sesuai dengan agenda yang telah direncanakan.

\section{SIMPULAN}

Pelatihan pengembangan
permainan untuk meningkatkan kemampuan sosial emosional anak dapat menambah pengetahuan dan wawasan tentang ragam permainan dan penerapannya dalam kegiatan anak. Adapun permainan yang disimulasikan adalah permainan bola perkenalan, jalan kepiting, lompati simpai, bola beranting, gobag bundar simpang tiga, guru berkata...., berbaris sesuai urutan angka, urutkan dengan garis, ayo.....mengurutkan, gambar berantai, pesan berantai, cerita berantai, pindahkan aku, aku berguna untuk...., tebak benda, tebak gerak, menggiring balon, mencari teman, mencari potongan yang sesuai, awal sebuah kata, bantu aku menemukan, memilih kemudian menggunting dan menempel, estafet bendera (merangkak, melompat, berlari), ambilkan sepatuku, kapal karam, dan pijat, palu, babat. Diharapkan melalui pelatihan tersebut, dapat meningkatkan pengetahuan dan memberikan motivasi para guru untuk mengembangkan serta menerapkan metode permainan yang variatif dalam kegiatan anak. 


\section{DAFTAR PUSTAKA}

Adi Soenarno. (2006). Leadership Games untuk Pelatihan Manajeman. Yogyakarta: Andi Offset.

Agoes Dariyo. (2007). Psikologi Perkembangan Anak Tiga Tahun Pertama. Bandung: Refika Aditama.

BEF Montolulu. (2009). Bermain dan Permainan Anak. Jakarta: Universitas Terbuka.

Johnson, J.E Christie, J.F Yawkey, T.D. (1999). Play and Early Childhood Development. New York: Longman.

Mayke Tedjasaputra. (1990). Bermain, Mainan, dan Permainan. Jakarta: Grasindo.

Moeslichatoen. (2004). Metode Pengajaran di Taman Kanakkanak. Jakarta: PT Rineka Cipta. 